The main features of the Hydraulics Laboratory are a level flume, $3 \mathrm{ft}$. wide, $2 \mathrm{ft}$. $6 \mathrm{in}$. deep, with an overall length of $82 \mathrm{ft}$. and glass sides to allow of easy observation; a smaller flume with one end capable of being given a maximum tilt of 1 in 20 ; a river model table $10 \mathrm{ft}$. wide and $70 \mathrm{ft}$. long for the study of river and tidal flow; and a general purpose bench for experiments on the flow of water in pipes.

In the Structures Laboratory, a 350,000-lb. precision hydraulic testing machine has been installed for compression and bending tests. This is fitted with an automatic loading device giving ten different rates of loading and reading to the nearest $10 \mathrm{lb}$. A 75,000-1b. machine for tensile tests and permitting of compression and bending tests on short struts and beams is on order and will have autographic loaddeformation recording apparatus. There are also several test-beds for testing members and structures, and the accessories provided are of the latest types.

The investigation of structural problems by various methods of mechanical analysis employing smallscale models will be carried out in the Model Analysis Laboratory, the equipment of which includes a Continostat apparatus for the experimental determination of influence lines using spline models and a Lobban deformeter. In the Highway Engineering and Materials of Construction Laboratory the main space has been divided into three sections: (1) tar, bitumen and asphalt; (ii) soils and aggregates; (iii) cement and concrete. Each has been suitably provided with apparatus and equipment which will enable tests and investigations to be carried out in conformity with present-day practice in this field, in which there is so much scope for development.

\title{
IRISH SALMON, SEA TROUT AND EELS
}

$\mathrm{T}$ HE Fisheries Branch of the Irish Department of Agriculture has published a brief summary of the catch of salmon, sea trout and eels in Eire between 1927 and 1939*. Alternate years only are given, the figures are neither averaged nor compared, and no comments are made or interences drawn. But the statistics themselves are of no small interest, as the following epitome of part of them is enough to show.

\begin{tabular}{|c|c|c|c|c|c|c|c|}
\hline & 1927 & 1929 & 1931 & 1933 & 1935 & 1937 & 1939 \\
\hline $\begin{array}{l}\text { Salmon } \\
\text { Total eatch (wt.) } \\
\text { do. rod only }\end{array}$ & $\left\{\begin{array}{l}100 \\
100\end{array}\right.$ & $\begin{array}{l}48 \\
24\end{array}$ & $\begin{array}{l}75 \\
53\end{array}$ & $\begin{array}{l}68 \\
31\end{array}$ & $\begin{array}{l}78 \\
50\end{array}$ & $\begin{array}{l}45 \\
38\end{array}$ & $\begin{array}{l}46 \\
34\end{array}$ \\
\hline $\begin{array}{l}\text { Average wt. per } \\
\text { flsh (lb.) }\end{array}$ & $\left\{\begin{array}{l}12 \cdot 9 \\
100\end{array}\right.$ & $\begin{array}{l}13 \cdot 5 \\
105\end{array}$ & 75 & $\begin{array}{l}11 \cdot 8 \\
91\end{array}$ & $7 \cdot 9 \cdot 8$ & $\begin{array}{l}10 \cdot 7 \\
83\end{array}$ & $\frac{10 \cdot 2}{79}$ \\
\hline $\begin{array}{l}\text { Value per rod } \\
\text { (shillings) }\end{array}$ & $\left\{\begin{array}{l}189 \\
100\end{array}\right.$ & $\begin{array}{l}77 \\
41\end{array}$ & $\begin{array}{l}85 \\
45\end{array}$ & $\begin{array}{l}66 \\
40\end{array}$ & $\begin{array}{l}84 \\
49\end{array}$ & $\begin{array}{l}69 \\
37\end{array}$ & $\begin{array}{l}72 \\
38\end{array}$ \\
\hline $\begin{array}{l}\text { Sea Trout } \\
\text { Total catch (wt.) }\end{array}$ & 100 & 101 & 101 & 91 & 100 & 96 & 101 \\
\hline
\end{tabular}

The period is not long enough, nor the data complete enough, to let us speak of any lasting trend; but it is clear that the catch of salmon has greatly diminished of recent years. Since 1927, the annual catch (as shown in alternate years) has never reached

* Eire: Roinn Talmhaidheachta (Department of Agriculture), Brainse Iascaigh (Fisheries Branch). Statistics of Salmon, Sea Trou and Eels captured during each of the Years 1939, 1937, 1935, 1933, $1931,1929,1927$. (P. No. 4658.) Pp. 20. (Dublin: Stationery Office, 1941.) $6 d$.
80 per cent, and has three times out of six been less than 50 per cent, of that year's catch. The catch by rod is worse still; for it has been so low as a quarter, and has only once been more than a half, of the catch of 1927. On the other hand, the catch of sea trout, while it has its ups and downs in the various rivers, averages out over all to a nearly constant total, year by year.

More remarkable than the diminished eateb of salmon is a diminution in the average weight of the same fish. From 1931 onwards the average weight has been much below that of 1927-29; and in the last five annual periods it has only averaged about four-fifths of the weight in the first two.

The returns from the several rivers or fishery districts show many interesting things. We have seen that the salmon catch of 1939 was only 46 per cent of that of 1927 ; but the decrease, though it extended well-nigh all round the coast of Eire, was very far from uniform. The three contiguous east coast districts, Dundalk, Drogheda and Dublin, had in $1939,90,99$ and 90 per cent of the catch of 1927 ; but the next succeeding regions, on the south-west and south coasts, namely, Wexford, Waterford, Lismore, Cork and Bandon, show only 34, 38, 26, 21 and 19 per cent, in the same comparison. The commercial importance of all these statistics is, as usual, the least interesting part of them. $\quad$ D. W. T.

\section{ELECTRIC STRENGTH OF SOLID DIELECTRICS}

N a paper, by W. G. Standring, of the National
Physical Laboratory, which is published in the
Power Engineering Section of the Journal of the
Institution of Electrical Engineers, of August, a dis-
cussion is given of the behaviour of a number of insu-
lating materials under disruptive voltages. Experi-
ments were carried out with the object of filling large
gaps in our knowledge in a field which has only been
partially explored. At the present time, a knowledge
of electric strength is of twofold interest. It is of
fundamental importance to the engineer, and values
of electric strength should provide guidance to the mathematical physicist in developing theories to explain the mechanism of electric breakdown.

Measurements of the electric strength of solid dielectrics have been made on samples up to a few millimetres in thickness. The values obtained are of the same order as those maintained on thin samples under maintained voltages. They indicate that a solid dielectric has a characteristic strength or gradient which causes breakdown, independent of thickness and not greatly dependent on the rate of application, or on the duration of the stress. Continental physicists have formed a similar conclusion for liquids. 